\title{
Physiological Workload and Health Hazards of Tribal Women of Meghalaya Involved in Weeding Operation
}

\author{
Swapnali Borah* and Nilakshi Borah \\ College of Community Science, Central Agricultural University, Tura, Meghalaya, India \\ *Corresponding author
}

\section{A B S T R A C T}

\begin{tabular}{l} 
K e y w o r d s \\
$\begin{array}{l}\text { Physiological } \\
\text { workload, Weeding } \\
\text { operation, } \\
\text { Vegetable } \\
\text { cultivation, Garo } \\
\text { tribal women, } \\
\text { Cardiovascular } \\
\text { stress, Perceived } \\
\text { health hazard }\end{array}$ \\
$\begin{array}{l}\text { Article Info } \\
\text { Accepted: } \\
18 \text { November } 2020 \\
\text { Available Online: } \\
10 \text { December } 2020\end{array}$ \\
\hline
\end{tabular}

\section{Introduction}

Meghalaya is one of the most scenic states of India, contributing a rich cultural heritage, variety of sylvan surroundings and luxurious vegetation comprising of a huge array of flora and fauna. In Meghalaya above 83 percent of entire population mostly depends on agricultural activities for their livelihood (Solomon et al., 2006). The state offers extent for cultivation of an ample variety of agricultural crops because of highly diversified topography, elevation and climatic

\begin{abstract}
Weed operation under vegetable cultivation was one of the most tiresome, repetitive and time consuming activities. Forty Garo tribal women farmers with two age group (20$35 y e a r s$ and 36-50years) from two villages namely Aminda Rangsagre and Aminda Simsanggre of Gambegre block of West Garo Hills were selected purposively to determine physiological responses, cardiovascular stress and health hazards of women farmers who had involved in weeding activity specifically. Results revealed that most of the tribal women were doing weeding activity with an average heart rate and peak heart rate of $108.7 \mathrm{bpm}$ and $127.2 \mathrm{bpm}$ respectively and further analysis showed that the average heart rate and peak heart rate of older age group women was higher than the younger age. Weeding activity was perceived as moderately heavy by rural tribal women and the cardiovascular stress index was 25.18 which was in higher side. Perceived physiological health hazards were also high as farm women reported that they had pain in upper and lower back, upper arm, wrist and thigh/knees/legs and causative factors were unnatural posture, repetitiveness of work and used poor designing farm tool. Environmental, doing weeding in vegetable cultivation.
\end{abstract}

conditions. In Meghalaya cultivation of vegetable is more than other crop cultivation because of hilly terrain and the favorable agro climatic condition. It is famous for a large array of vegetables both sub-tropical and temperate. About $78 \%$ of women are engaged in different activities under agriculture as compared to $63 \%$ of all economically active men (Singh et al., 2020).

Rural tribal farm women of Meghalaya are contributed to agricultural work in addition to household activities like producing agricultural 
crops, preparing food, working in rural enterprises, involving in trade and marketing, cleaning animals, maintaining their homes and caring family members. As the state is a tribal dominating area where matrilineal society is prevalent and women of this hilly state feel proud of doing agricultural and related activities along with household chores (Borah, 2015). The daily work schedule of rural women is very challenging and laborious. Hill farm women are also fetching water and collection of firewood from faraway places in hilly terrain. Women as farmer or farm workers, take part in some activities such as land preparation, fertilizer application, weeding, transplanting, plant protection, harvesting, processing, selling, winnowing, storing, etc (Sudharani and Raju, 1991). In case of activities under vegetable cultivation though both male and female were involved, but in some activities like weeding, cleaning etc. where female participation was more as these activities are time consuming, monotonous, repetitive nature of work and tedious which leads to drudgery and fatigue. Though in national level feminization and modernization of agriculture has been developing in rapid pace, still women have to perform agricultural operations with conventional age old farm tool. In Meghalaya women use only khurpi and sickle for weeding which are poorly designed and not at all women friendly. Weeding operation perceived by farm women was high drudgery prone activity with a drudgery scale value of 2.01 which was followed by other agricultural operations (Kishtwaria and Rana, 2012). Farm women involved in weeding were also affected by some work related health hazards, pain in different parts of their body due to adoption of awkward body posture which unfavorably affect their work efficiency and welfare of family. Considering all these aspects the study was envisaged to estimate the cardiovascular stress and health hazards of rural tribal women of Meghalaya involved in weeding operation.

\section{Materials and Methods}

A total of 40 farmers from two villages namely Aminda Rangsagre and Aminda Simsanggre of Gambegre block of West Garo Hills of Meghalaya, India involved in vegetable cultivation were selected purposively with two age groups (20-35years and 36-50years) who were involved in weeding activity specifically and who had body temperature not above $99^{\circ} \mathrm{F}$, blood pressure within the range of 120/80 \pm 10 and heart rate within the range of $70-90$ beats per minute $(\mathrm{bpm})$ were selected.

\section{Method of measuring the physiological parameters of farm women during weed management}

Following methods were used for measuring the physiological parameters during weed management under vegetable cultivation

\section{Cardiovascular stress}

Heart rate (beats/min) was measured with the help of polar rate monitor, which consisted of one transmitter and one receiver to transmit and received the ECG signals. Transmitter was tied on the chest of the subject and receiver was tied on the wrist and ECG signals were recorded at rest, during the entire period of work and recovery thereafter for a period of 5 minutes. Recording of heart rate with this method is very simple and less time consuming. At the same time is equally reliable method to measure physiological workload.

\section{Energy expenditure}

This method has been in extensive use in work physiology since long (Christensen, 1953; Durin and Passmore, 1967; Saha and Banerjee, 1976). Energy expenditure was estimated from average heart rate during rest 
and during work by using following formula for Indian housewives (Varghese et al 1994).

Energy Expenditure $(\mathrm{kj} / \mathrm{min})=0.159 \times$ Average heart rate (beats/min) - 8.72

\section{Classification of physiological workload}

Physiological workload was classified on the basis of heart rate and presented in the Table below (Varghese et al., 1994):

\begin{tabular}{|l|c|}
\hline $\begin{array}{l}\text { Physiological } \\
\text { workload }\end{array}$ & $\begin{array}{c}\text { Physiological } \\
\text { variable (Heart rate) }\end{array}$ \\
\hline Very light & Up to 90 \\
\hline Light & $91-105$ \\
\hline Moderately heavy & $106-120$ \\
\hline Heavy & $121-135$ \\
\hline Very heavy & $136-150$ \\
\hline Extremely heavy & Above 150 \\
\hline
\end{tabular}

Total cardiac cost of work (TCCW) and physiological cost of work (PCW)

Total cardiac cost of work (TCCW) and physiological cost of work (PCW) were determined in this study by using average heart rate during rest and work, recovery heart rate and duration of work and recovery through the following formulas:

Total cardiac cost of work $=$ Cardiac cost of work + Cardiac cost of recovery

(TCCW) (CCW) $\quad$ (CCR)

Where, $\mathrm{CCW}=\mathrm{AHR} \times$ Duration of work

AHR = (Average working heart rate Average resting heart rate)

$\mathrm{CCR}=$ (Average Recovery heart rate Average resting heart rate) $\times$ Duration of recovery

Physiological Cost of work $=\frac{\text { Total Cardiac cost of work }}{\text { Total time of work }}$

\section{Cardio vascular stress index}

Cardiovascular Stress Index (CSI) was determined by using following formula given by Trites et al., 1993.

$$
\text { CSI }=\frac{100 \text { (Heart rate during work-heart rate during rest) }}{\text { Heart rate maximum-Heart rate at rest }}
$$

Where, Heart rate maximum $=220-$ Age (years)

\section{Results and Discussion}

\section{Physiological responses}

Physiological responses viz. heart rate and peak heart rate, energy expenditure and peak energy expenditure, total cardiac cost of work (TCCW), physiological cost of work (PCW), cardiovascular stress index (CSI) and workload were calculated for weed management under vegetable cultivation and presented in Table 1. It was noted that total average heart rate and peak heart rate were 108.7 and $127.2 \mathrm{bpm}$ respectively which showed that the average heart rate and peak heart rate of older age group women (3650years) was higher than younger age group women (20-35 years). These findings can be supported by a study conducted by Borah $\mathrm{S}$ (2015) on farm women in Meghalaya who are engaged in firewood collection and found that the average heart rate and peak heart rate of woman of older age group was higher than younger age group. The average energy expenditure and peak energy expenditure was evaluated as $8.57 \mathrm{kj} / \mathrm{min}$ and $11.5 \mathrm{kj} / \mathrm{min}$ respectively. It was also noticed that farm women of Haryana engaged in fodder collection activity with average energy expenditure $11.7 \mathrm{kj} / \mathrm{min}$ in a load of $43.8 \mathrm{~kg}$ on their head and work was graded as 'moderately heavy' (Gandhi et al., 2001). Earlier a study done on peeling and shelling of cashew nut in various cashew nut industries of Meghalaya and results showed 
that their average heart rate and average energy expenditure was $110.5 \mathrm{bpm}$ and 8.85 $\mathrm{kj} / \mathrm{min}$, where peak heart rate and peak energy expenditure was $117.58 \mathrm{bpm}$ and $9.96 \mathrm{kj} / \mathrm{min}$, respectively (Borah S 2015). Again it was observed that (Table 2) the physiological work load of weeding activity was categorized as 'moderately heavy' based on heart rate and energy expenditure. Chauhan (1991) reported that the physiological workload ranged from 'very light to moderately heavy' while study on basket making. Another study conducted in Meghalaya, on cashew nut industry among women workers engaged in shelling and peeling activity reported that the physiological workload of both the activity was rated as 'moderately heavy' based on their heart rate and energy expenditure (Borah $S$ 2015). TCCW and PCW were determined while doing weeding in vegetable cultivation and they are on an average 4740 beats and $26.33 \mathrm{bpm}$ respectively. Again from the Table 2 it is observed that CSI of farm women involved in weeding activity under vegetable cultivation were 25.18 which were quite higher than steel workers (Vitalis et al., 1994), cashew nut workers (Borah S 2010) and car assembly workers (Goldsmith et. al 1978). CSI among group of workers may vary due to harshness of job, environmental conditions, mode of work and also duration of work. In case of weeding activity as farm women working under scorching sun for long hours in vegetable field may lead to increase cardiovascular stress. In previous study showed that the CSI of rural women engaged in firewood collection was higher than the weeding activity as they had to carry a heavy load of firewood in kokcheng (a native bamboo basket) on their back in hilly terrain of Meghalaya (Borah, 2015).

Table.1 Physiological responses of farm women during weed management

\begin{tabular}{|l|c|c|c|}
\hline \multicolumn{1}{|c|}{$\begin{array}{c}\text { Parameter } \\
\text { (Average) }\end{array}$} & $\begin{array}{c}\text { Weed } \\
\text { Management } \\
(\mathbf{2 0 - 3 5} \mathbf{y r s}) \\
\mathbf{n = 2 0}\end{array}$ & $\begin{array}{c}\text { Weed } \\
\text { Management } \\
(\mathbf{3 6 - 5 0} \text { yrs }) \\
\mathbf{n = 2 0}\end{array}$ & $\begin{array}{c}\text { Total } \\
\mathbf{( 2 0 - 5 0} \text { yrs) } \\
\text { N=40 }\end{array}$ \\
\hline Heart Rate (bpm) & 107.3 & 110.2 & 108.7 \\
\hline Peak Heart Rate (bpm) & 125.15 & 129.25 & 127.2 \\
\hline Energy Expenditure (kj/min) & 8.34 & 8.80 & 8.57 \\
\hline Peak Energy Expenditure & 11.17 & 11.83 & 11.5 \\
\hline $\begin{array}{l}\text { Total Cardiac Cost of Work } \\
\text { (beats) }\end{array}$ & 4390.5 & 5089.5 & 4740 \\
\hline Physiological Cost of Work (bpm) & 24.39 & 28.27 & 26.33 \\
\hline Cardiovascular Stress Index & 21.84 & 28.52 & 25.18 \\
\hline Work load & Moderately & Moderately & Moderately \\
heavy & heavy & \\
\hline
\end{tabular}

Table.2 Comparison of Cardiovascular Stress Index (CSI) between weed management and other works

\begin{tabular}{|c|c|c|c|c|}
\hline $\begin{array}{c}\text { Work } \\
\text { category }\end{array}$ & $\begin{array}{c}\text { Weed } \\
\text { Management }\end{array}$ & $\begin{array}{c}\text { Steel } \\
\text { workers }\end{array}$ & $\begin{array}{c}\text { Cashew nut } \\
\text { workers }\end{array}$ & $\begin{array}{c}\text { Car assembly } \\
\text { workers }\end{array}$ \\
\hline CSI & $25.18 \pm 3.96$ & $25.0 \pm 14.0$ & $23.82 \pm 2.05$ & $20.0 \pm 7.0$ \\
\hline
\end{tabular}


Table.3 Perceived health hazards of farm women involved in weed management

\begin{tabular}{|c|c|c|}
\hline Health hazards & Causative Factor & $\begin{array}{l}\text { Types of } \\
\text { hazards }\end{array}$ \\
\hline Upper and lower back pain & $\begin{array}{l}\text { Adopted bending posture while weeding in } \\
\text { vegetable field }\end{array}$ & Physical \\
\hline Pain in upper arm & Repetitive nature of activity & Physical \\
\hline Wrist pain & $\begin{array}{l}\text { Repetitiveness of activity and using } \\
\text { traditional weeding tool like khurpi, sickle }\end{array}$ & Physical \\
\hline Pain in thigh/legs/knee & $\begin{array}{l}\text { Due to sitting long hours and adopted } \\
\text { squatting posture }\end{array}$ & Physical \\
\hline Headache & Working under scorching sun, & Environmental \\
\hline Wound in hand/fingers & While doing weeding with sickle and khurpi & Mechanical \\
\hline Uterus prolapsed & Due to prolong squatting posture & Physical \\
\hline Insect/snake bite & Cultivator area are in or near forest & Zoonotical \\
\hline
\end{tabular}

\section{Perceived health hazards}

Health hazards of farm women involved in weeding operation were recorded, causative factors were analyzed and type of hazards were noticed (Table 3). Farm woman had lots of physical injuries including pain in upper and lower back, upper arm, wrist pain and pain in thigh/legs/knee due to adoption of squatting posture for long hours along with bending or stooping posture, repetitiveness of work and use of traditional age old hand tools. Hasalkar et al., in year 2017 reported that the majority of the women complained very severe to severe pain in shoulder joint, upper arm, low back wrist/hands and knees while performing top dressing of fertilizer by traditional tool compared to improved tool. In another study done by Verma et. al (2019) on weeding activity and results showed that maximum farm women were suffering from the pain in thigh and hand followed by back, knee, wrist and shoulder. Therefore it is concluded that there are the symptoms of some musculoskeletal disorders which occur due to awkward postures and repetitive motions while doing this activity. Environmental health hazard leading to headache was also reported by the farm women because of working in vegetable field under scorching sun. Rural farm women workers had mechanical hazards like wound in hand/fingers as working with old traditional tool (khurpi and sickle). Again it was reported that some of the women perceived their uterus prolapsed due to prolong squatting posture. Insects/snake bites were common problem among farm women as their cultivation area was in or near forest. Borah and Borah (2020) also reported that rural Garo women faced problem and health hazards due to snake/leech bite along with cuts/bruises in their fingers, hands etc. while collecting Castor and Kesseru leaves for silk worm in rural areas of East Garo Hills of Meghalaya.

Based on above findings it can be concluded that weeding activity was tiresome, repetitive in nature as well as involvement of women was more than men therefore women were more vulnerable than men in case of health related issues like pain in different parts of body, work related musculoskeletal disorders (WMSDs) etc. Grooten et al., (2007) stated that repetitive and monotonous work was a strong risk factor for musculoskeletal problems. In terms of average heart rate and peak heart of older age group women (3650years) was higher than the younger age 
women. The physiological workload of women engaged in weeding operation was categories as moderately heavy activity and CSI was comparatively higher than other industrial workers because farmers involved in weeding operation were worked under scorching sun for long duration of time which may leads to increase cardiovascular stress. The women workers working in vegetable cultivation for longer period of time in a squatting as well as bending posture during weed management and have resulted in pain in upper and lower back, upper arm, thigh/legs/knees and sometimes major health hazards like uterus prolapsed. It was found that in weeding activity farm women had wounds in their fingers/hands while using conventional age old khurpi, sickle etc. Therefore ergonomically designed women friendly tools can be developed and suggest to reduce their health related issues, decreases WMSDs, reduce cuts/wounds while doing weeding activity. Ergonomics interventions are necessary for reducing physiological cost, health related hazards, improving productivity, decreasing drudgery of women while working and need of an awareness, knowledge and training programme for mitigating occupational health hazards and safety of women workers.

\section{Acknowledgement}

This is a part of the project of AICRP-Home Science (FRM component), funded by CIWA, ICAR, Bhubaneswar.

\section{References}

Borah S. (2015) Physiological workload of hill farm women of Meghalaya, India involved in firewood collection. Procedia Manufacturing, 3: 4984 4990

Borah S. and Borah N (2020) Prevalence of Ergonomics Risks and Health Hazards in Sericultural Activities Performed by Hilly Tribal Women of East Garo Hills of Meghalaya, India. Anthropologist, 39(1-3): 9-16

Borah, S. (2010) Ergonomic Assessment of Women Workers engaged in Cashew nut factory of Meghalaya. Intramural Research Project of Central Agricultural University, India.

Borah, S. (2015) Ergonomic Assessment of Drudgery of Women Worker Involved in Cashew Nut Processing Factory in Meghalaya, India. Procedia Manufacturing, 3: 4665-4672.

Chauhan, M.K. (1991) Occupational workload of women basket makers. M.Sc. thesis, SNDT Women's University, Bombay.

Christensen, E. H. (1953) Physiological valuation of work in Nykroppa iron works. In Symposium on fatigue (pp. 93108). London: Lewis.

Durin J. V. G. A. and Passmore R (1967) Energy, work and leisure. Heinemann Education Book, London. 1967.

Gandhi S, Dilbaghi M, Rana K, and Singh R (2001) Fodder collection by farmwomen of Haryana - An ergonomic study. Paper presented in International Congress on Humanizing Work and Work Environment, IIT, Mumbai.

Goldsmith R, O’ Brien C, Tan G.L.E, Smith W.S, and Dixon M (1978) The cost of work on a vehicle assembly line, Ergonomics. 21: 315- 323.

Grooten WJA, Mulder M, Josephson M, Alfredsson L, Wiktorin C (2007) The influence of work-related exposures on the prognosis of neck/shoulder pain. European Spine Journal, 16(12):20832091

Haslkar S, Shivalli R, and Budihal R (2007) Musculoskeletal disorder of the farm women while performing top dressing and fertilizer activity. Journal of Human Ecology 21(2): 109-112. 
Kishtwaria J. and Rana A (2012) Ergonomic interventions in weeding operations for drudgery reduction of hill farm women of India.41:4349-4355.

Saha P. N and Banerjee P. K (1976) Prediction of energy expenditure from working heart rate in industrial work situations. American Industrial Hygiene Association Journal 36: 1-4.

Singh K. M, Kumai P, and Ahmed N (2020, January 7) An Analysis of Women's Participation in Agriculture in Bihar.

Solomon RDNJ, Roytre Christopher Laloo, and Mishra Bhanu Prakash (2006) Traditional agricultural practices in Meghalaya, North East India. Indian Journal of Traditional Knowledge. 5(1):7-18.

Sudharani P. and Raju V.T (1991) Participation of women in agricultural operations. Indian J of Ext. Edu. 28 (1 and 2): 54-59.
Trites D. G, Robinson D. G and Banister, E. W (1993) Cardiovascular and muscular strain during a tree planting season among British Columbia silviculture workers, Ergonomics. 36 935-949.

Varghese M. A, Atreya N, and Saha P. N (1994). A rapid appraisal of occupational workloads from a modified scale of perceived exertion. Ergonomics, 37(3): 485-491.

Verma R, and Singh V (2019) Health Problems Faced by Farm Women during Weeding Activity. Indian Journal of Ecology Special Issue-1: 000-000, Manuscript Number: 2821

Vitalis A, Pournaras N.D, Jeffery G.B, Tsagarakis G, Monastiriotis G, and Kavvadias S. (1994) Heart rate strain indices in Greek steelworkers, Ergonomics. 37: 845 - 850

\section{How to cite this article:}

Swapnali Borah and Nilakshi Borah. 2020. Physiological Workload and Health Hazards of Tribal Women of Meghalaya Involved in Weeding Operation. Int.J.Curr.Microbiol.App.Sci. 9(12): 2589-2595. doi: https://doi.org/10.20546/ijcmas.2020.912.306 